University of Nebraska - Lincoln

DigitalCommons@University of Nebraska - Lincoln

$1-15-2001$

\title{
Evaluation of gel filtration resins for the removal of PCR-inhibitory substances from soils and sediments
}

Daniel N. Miller

University of Nebraska-Lincoln, dan.miller@ars.usda.gov

Follow this and additional works at: https://digitalcommons.unl.edu/usdaarsfacpub

Part of the Agricultural Science Commons

Miller, Daniel N., "Evaluation of gel filtration resins for the removal of PCR-inhibitory substances from soils and sediments" (2001). Publications from USDA-ARS / UNL Faculty. 187.

https://digitalcommons.unl.edu/usdaarsfacpub/187

This Article is brought to you for free and open access by the U.S. Department of Agriculture: Agricultural Research Service, Lincoln, Nebraska at DigitalCommons@University of Nebraska - Lincoln. It has been accepted for inclusion in Publications from USDA-ARS / UNL Faculty by an authorized administrator of DigitalCommons@University of Nebraska - Lincoln. 


\title{
Evaluation of gel filtration resins for the removal of PCR-inhibitory substances from soils and sediments ${ }^{\text {h }}$
}

\author{
Daniel N. Miller* \\ U.S. Meat Animal Research Center, USDA, ARS, Clay Center, P.O. Box 166, Nebraska 68933, USA
}

Accepted 17 October 2000

\begin{abstract}
A variety of gel filtration resins (Sephadex G200 and G150; Sepharose 6B, 4B and 2B; Bio-Gel P100, P200; and Toyopearl HW 55, HW 65, and HW 75) were evaluated for their efficacy in removing PCR-inhibitory substances from feedlot soil DNA crude extracts using gravity-flow disposable columns. Sepharose resins demonstrated the best properties for DNA purification when compared to other gel filtration resins, and Sepharose 2B was the most efficient purification resin based upon flow rate and the elution of DNA and humic acids from the columns. A method for purifying large solution volumes of DNA extract economically was also developed using low-cost disposable Disposaflex columns. Crude DNA extracts of cattle feedlot soil and aquifer sediment impacted by animal and human wastes were easily purified using the Disposaflex column method regardless of whether a gentle chemical lysis or a bead mill homogenization DNA extraction method was employed. (C) 2001 Elsevier Science B.V. All rights reserved.
\end{abstract}

Keywords: DNA Extraction; PCR; Purification; Sediment; Size exclusion chromatography; Soil

\section{Introduction}

Application of molecular techniques in the field of environmental microbiology has provided microbiologists new insights into microbial communities. Efficient extraction and purification of nucleic acids from soils and sediments, however, remains a challenge. Numerous extraction methods have been developed and evaluated (Leff et al., 1995; Miller et

\footnotetext{
Names are necessary to report factually on available data; however, the USDA neither guarantees nor warrants the standard of the product, and the use of the name by USDA implies no approval of the product to the exclusion of others that may also be suitable.

* Tel.: +1-402-762-4208; fax: +1-402-762-4209.
}

al., 1999; Moré et al., 1994; Steffan et al., 1988; Zhou et al., 1996), but all methods yield crude extracts that are contaminated to varying degrees with substances that inhibit key enzymatic processes in molecular biological methods. Humic acids are the most widely reported contaminant in soil and sediment nucleic acid extracts (Wilson, 1997 and references therein), but other constituents, such as metals and polysaccharides, can also inhibit molecular reactions (Straub et al., 1995; Tsai and Olson, 1992). Typically, inhibitory substances are removed using spin columns packed with various resins. Gel filtration (also known as size exclusion) resins have seen the widest application, but only a few resins have been rigorously evaluated (Jackson et al., 1997). Additionally, crude extract capacity in spin columns 
is limited to a maximum of a few hundred microliters making crude extract concentration necessary.

The aims of this study were to evaluate a variety of gel filtration resins for their ability to separate microbial DNA from humic substances co-extracted from soils and sediments and develop a low-cost, high throughput method for purifying large extract sample volumes. Two samples - cattle feedlot drainage ditch soil and subsurface aquifer sediment - were selected to evaluate the purification method. Two DNA extraction methods - gentle chemical lysis and harsher bead mill homogenization - were used to prepare DNA extracts of varying quality. We found that Sepharose resins proved to be superior to all other resins tested, regardless of sample origin and DNA extraction method employed.

\section{Materials and methods}

\subsection{Soil and sediment sampling and characterization}

Cattle feedlot soil samples were collected at the 6000 head capacity feedlot at the USDA-ARS, U.S. Meat Animal Research Center located in south central Nebraska. Soil core samples were taken from a feedlot drainage ditch using an open ended, $60 \mathrm{ml}$ syringe coring device $(10 \mathrm{~cm}$ core depth, $2.5 \mathrm{~cm}$ core diameter). After coring, the open end of the core was plugged with a rubber stopper, transported to the laboratory, extruded into a $500 \mathrm{ml}$ lyophilization flask, frozen, and lyophilized overnight. Dried feedlot ditch sediment was then ground to a fine powder with a mortar and pestle, transferred to a $250 \mathrm{ml}$ bottle, and stored at $-20^{\circ} \mathrm{C}$. To minimize sample contamination, all surfaces that came into contact with the sample were either autoclaved or rinsed in series with a $10 \%$ Clorox solution and sterile $\mathrm{H}_{2} \mathrm{O}$.

Aquifer sediments were collected from a freshwater sand and gravel aquifer located on Cape Cod near Falmouth, Massachusetts, where disposal of dilute, treated sewage has resulted in a large, oxygen-depleted plume of contaminated ground water (4 $\mathrm{km}$ long). Inorganic nitrogen (ammonia and nitrate) is a significant plume component, with concentrations often exceeding $1 \mathrm{mM}$ (LeBlanc, 1984; Savoie and LeBlanc, 1998; Smith et al., 1991). Dissolved organic carbon in the plume is $2-4 \mathrm{mg}^{-1}$ and is composed of mostly refractory compounds (Barber et al., 1988; Harvey and Barber, 1992). Several sediment cores were collected with a wireline piston core barrel through hollow stem augers (Zapico et al., 1987) from a wastewater infiltration bed spanning a depth of 7.3-26.2 m below land surface (land surface elevation $=21.0 \mathrm{~m}$ ). The core barrel was fitted with a $5.1 \mathrm{~cm}$ diameter, polycarbonate liner, which was divided into sections upon retrieval. Each segment was capped, stored at $4^{\circ} \mathrm{C}$, and transported to the laboratory (1-2 days for sample collection and transportation). At the laboratory the aquifer sediments were expelled from each core segment, mixed, weighed into $50 \mathrm{ml}$ plastic centrifuge tubes or Whirl Pac bags, and frozen at $-20^{\circ} \mathrm{C}$ until extraction. One core section (10.4-12.4 m below land surface) was selected for this study.

The general characteristics of the feedlot soil and aquifer sediments are listed in Table 1. Dry matter content and organic matter content of the samples were measured by weight differences upon drying at $100^{\circ} \mathrm{C}$ and after combusting the sample overnight at $560^{\circ} \mathrm{C}$, respectively. Total $\mathrm{C}$ and $\mathrm{N}$ were measured on the dried composites using a LECO CN-2000 carbon/nitrogen analyzer (LECO Corp., St. Joseph, MI). Soil $\mathrm{pH}$ was determined in distilled $\mathrm{H}_{2} \mathrm{O}$ slur-

Table 1

Characteristics of the cattle feedlot drainage ditch and aquifer sediments ${ }^{\mathrm{a}}$

\begin{tabular}{llllll}
\hline Sediment & Dry matter $(\%)$ & Organic matter $(\%)^{\mathrm{b}}$ & Total N $(\%)^{\mathrm{b}}$ & ${\text { Total C }(\%)^{\mathrm{b}}}^{\mathrm{pH}}$ \\
\hline Cattle feedlot & 69.5 & 14.3 & 0.83 & 7.8 & 7.92 \\
Aquifer & 85.9 & 0.3 & BD & 0.02 & 5.97 \\
\hline
\end{tabular}

${ }^{\mathrm{a}}$ Dry matter, organic matter, total $\mathrm{N}$, and total $\mathrm{C}$ determined from frozen bulk aquifer sediment. The $\mathrm{pH}$ was determined from a fresh collected ground water sample using a multilevel sample well and peristaltic pump.

${ }^{\mathrm{b}}$ Expressed on a dry matter basis.

${ }^{\mathrm{c}} \mathrm{BD}=$ Below detection $($ Total $\mathrm{N}$ detection limit $=0.002 \%)$. 
ries $(33 \% \mathrm{w} / \mathrm{v})$ using a combination $\mathrm{pH}$ electrode and PHM 80 Portable $\mathrm{pH}$ meter (Radiometer Analytical, Westlake, $\mathrm{OH})$.

\subsection{DNA extraction and quantification from the feedlot soil and aquifer sediment}

Bacterial DNA crude extracts from the cattle feedlot soil were prepared by one of two methods. The first DNA extraction method, gentle chemical lysis, extracted high molecular weight DNA in relatively low quantity. The second method, bead mill homogenization, extracted larger quantities of lower molecular weight DNA and was based upon the method described by Miller et al. (1999). In the gentle chemical lysis method, $2.5 \mathrm{~g}$ of feedlot soil sample were combined with $1.25 \mathrm{ml}$ of $0.5 \mathrm{M} \mathrm{NaH}_{2} \mathrm{PO}_{4}$ $(\mathrm{pH}), 1.875 \mathrm{ml}$ of lysis solution $(3 \mathrm{M} \mathrm{NaCl} ; 0.2 \mathrm{M}$ Tris $\mathrm{HCl}$; $0.2 \mathrm{M}$ EDTA; $\mathrm{pH} 8$ ) and $0.625 \mathrm{ml}$ of $12 \%$ SDS in a $15 \mathrm{ml}$ screw top tube. The extraction mixture was incubated at $65^{\circ} \mathrm{C}$ for 30 min with occasional mixing. After the mixture was cooled on ice, it was extracted once with $6.25 \mathrm{ml}$ of chloroform-isoamyl alcohol (24:1) and centrifuged at 1100 $\times g$ for $15 \mathrm{~min}$ in a Beckman J6-HC centrifuge (Beckman Coulter, Fullerton, CA). The upper aqueous phase was transferred to a new tube, and the DNA was precipitated by the addition of $40 \mu 13 \mathrm{M}$ sodium acetate and $8 \mathrm{ml} 100 \%$ ethanol at $-20^{\circ} \mathrm{C}$ overnight. After centrifuging for $20 \mathrm{~min}$ at $1100 \times \mathrm{g}$, the liquid was decanted, and the pellet was lyophilized. Nucleic acids were then dissolved in 2 $\mathrm{ml}$ sterile distilled $\mathrm{H}_{2} \mathrm{O}$, stored at $-20^{\circ} \mathrm{C}$, and served as a working crude extract for evaluation of gel filtration resins. A crude DNA extract was obtained from aquifer sediments using the same gentle chemical lysis procedure. Because bacterial abundance was much lower in the aquifer sediments, amount of sample and extraction volumes were increased, while incubation conditions remained the same. Briefly, $100 \mathrm{~g}$ of aquifer sediment were combined with $5 \mathrm{ml}$ of $0.5 \mathrm{M} \mathrm{NaH}_{2} \mathrm{PO}_{4}(\mathrm{pH} 8), 7.5 \mathrm{ml}$ of lysis solution (3 M NaCl; $0.2 \mathrm{M}$ Tris HCl; $0.2 \mathrm{M}$ EDTA; $\mathrm{pH}$ 8) and $2.5 \mathrm{ml}$ of $12 \%$ SDS in a $50 \mathrm{ml}$ screw top tube. After incubation, the sample was extracted with 15 $\mathrm{ml}$ of chloroform-isoamyl alcohol (24:1). Phases were separated by centrifugation $(1100 \times g$ for 15 min), and the upper aqueous phase (crude extract) was removed to a $50 \mathrm{ml}$ screw top tube. DNA was precipitated by adding $1.5 \mathrm{ml} 3 \mathrm{M}$ sodium acetate and $30 \mathrm{ml}$ ethanol. After centrifugation and drying, the pellet was dissolved in $4 \mathrm{ml} \mathrm{H}_{2} \mathrm{O}$ and stored at $-20^{\circ} \mathrm{C}$.

For the bead mill homogenization method (Miller et al., 1999), $0.5 \mathrm{~g}$ of the frozen, dried soil was added to a 2-ml homogenization vial containing $2 \mathrm{~g}$ 0.1-mm-diameter zirconium-silica beads (BioSpec Products, Bartlesville, OK), $500 \mu \mathrm{l}$ of sodium phosphate buffer (100 mM; pH 8), $500 \mu \mathrm{l}$ of SDS lysis mixture (100 mM NaCl, $500 \mathrm{mM}$ Tris [pH 8], 10\% [wt/vol] SDS), and $500 \mu \mathrm{l}$ of chloroform-isoamyl alcohol (24:1). Samples were mixed and homogenized using a Mini Bead Beater-8 (BioSpec Products) for $1 \mathrm{~min}$ on "homogenize" setting (roughly $2700 \mathrm{rpm})$. After centrifugation at $10000 \times g$ for 5 min, the upper aqueous phase (crude extract) was transferred to a $1.5-\mathrm{ml}$ microfuge tube and stored at $-20^{\circ} \mathrm{C}$. No precipitation was required to concentrate the DNA in the crude extract (final volume $=1.5$ $\mathrm{ml}$ ).

The DNA content of each crude extract was determined using agarose gel electrophoresis and image analysis as previously described (Miller et al., 1999). DNA content of each crude extract was determined by comparing the fluorescent intensity of the ethidium bromide-stained DNA crude extract band to the intensity of known amounts of BstEII digested $\lambda$ DNA. The average size and distribution of DNA fragments in the crude extracts were also determined by agarose gel electrophoresis $(0.8 \%$ agarose) with 1 $\mathrm{kb}$ extension ladder (Gibco BRL, Life Technologies, Inc., Rockville, MD) as a sizing standard using the public domain NIH Image program developed at the U.S. National Institutes of Health (http:// rsb.info.nih.gov/nih-image). Humic acid content was determined as described below and standardized to the humic acid content of the crude extract obtained from the cattle feedlot soil using the gentle chemical lysis extraction procedure. Characteristics of each DNA crude extract are listed in Table 2. DNA recoveries from each sample were $0.044,28.75$, and $112.9 \mu \mathrm{g}$ of DNA $\mathrm{gm}^{-1}$ (dry) soil for the aquifer sediment, cattle feedlot soil (gentle lysis), and cattle feedlot soil (bead mill homogenization), respectively. 
Table 2

Properties of the three DNA extracts evaluated in this study

\begin{tabular}{|c|c|c|c|c|}
\hline Extract & $\begin{array}{l}\text { DNA content } \\
\text { (ng/ } / \mu 1 \text { extract) }\end{array}$ & $\begin{array}{l}\text { DNA } \\
\text { size }(k b)^{a}\end{array}$ & $\begin{array}{l}\text { DNA size } \\
\text { range }(\mathrm{kb})\end{array}$ & $\begin{array}{l}\text { Humic acid } \\
\text { content }(\%)\end{array}$ \\
\hline Aquifer Sand (Gentle chemical extraction) & 1.10 & 15.6 & $40-8.1$ & 88.1 \\
\hline Feedlot Soil (Gentle chemical extraction) & 35.94 & 13 & $40-4.1$ & 100.0 \\
\hline Feedlot Soil (Bead mill homogenization) & 37.62 & 9.3 & $20-3.1$ & 33.6 \\
\hline
\end{tabular}

${ }^{\mathrm{a}}$ Zone of highest ethidium bromide intensity (i.e., greatest DNA content) in the sizing gel.

${ }^{\mathrm{b}}$ Relative to the humic acid content of the feedlot soil crude extract (gentle chemical lysis method).

\subsection{Gel filtration column purification}

Table 3 lists the gel filtration resins tested in this and their various properties. Resins were chosen based upon (i) their previous use purifying microbial DNA from soils and sediments, (ii) the resin chemical (polyacrylamide and agarose-based) and separation characteristics, and (iii) affordability. Flow rates in Table 3 were determined in duplicate Poly-Prep columns (Bio-Rad, Hercules, CA) using resin washed and equilibrated with high salt TE $(100 \mathrm{mM} \mathrm{NaCl}$, $10 \mathrm{mM}$ Tris, $1 \mathrm{mM}$ EDTA; pH 8). Final packed volume was $2 \mathrm{ml}$ (see below for method details). A measure of $1 \mathrm{ml}$ of high salt TE was loaded onto the column and allowed to flow through the column by gravity alone. At periods ranging from 1 to $5 \mathrm{~min}$, eluted liquid volume was determined. Flow rate is the linear regression of volume eluted versus time for four time points.

An initial screen of the resins was made using relatively low-volume, gravity-flow columns prepared in Poly-Prep columns, which have a $2 \mathrm{ml}$ resin capacity. Each of the resins was hydrated (if necessary) and washed several times in high salt TE to remove fines and/or storage buffer. Columns were then packed by gravity flow to a final volume of 2 $\mathrm{ml}$. Four volumes of high salt TE $(8 \mathrm{ml})$ were then passed through the column as a final equilibration step to remove any remaining resin storage buffer constituents. This was necessary because trace quantities of ethanol in the Sepharose resins interfered with subsequent spectrophotometric analyses. It should also be noted that special care was taken to ensure that the packed columns remained fully hydrated as channels could quickly develop and affect the separation of DNA from humic substances. Feedlot soil crude DNA extracts $(0.2 \mathrm{ml})$ were added to duplicate columns followed by several additions of $0.2 \mathrm{ml}$ high salt TE buffer. The eluate from each column was collected in $0.2-\mathrm{ml}$ fractions, which were frozen at $-20^{\circ} \mathrm{C}$ until analysis.

Based on the results of the initial resin screen, a low-cost, large volume column purification method was developed. Washed Sepharose 2B or 4B resin

Table 3

Properties of evaluated gel filtration resins

\begin{tabular}{lcll}
\hline Resin & $\begin{array}{l}\text { Bead size } \\
(\mu \mathrm{m})^{\mathrm{a}}\end{array}$ & MW fractionation range & $\begin{array}{l}\text { Flow rate } \\
(\mathrm{ml} / \mathrm{min})^{\mathrm{b}}\end{array}$ \\
\hline Sephadex G150 & $116-349$ & $1000-150,000$ & 0.43 \\
Sephadex G200 & $32-129$ & $1000-200,000$ & 0.25 \\
Sepharose 2B & $60-200$ & $100000-20,000,000$ & 0.39 \\
Sepharose 4B & $45-165$ & $30,000-5,000,000$ & 0.26 \\
Sepharose 6B & $45-165$ & $10,000-1,000,000$ & 0.27 \\
Bio-Gel P100 & $90-180$ & $5000-100,000$ & 0.20 \\
Bio-Gel P200 & $50-100$ & $30,000-200,000$ & 0.41 \\
Toyopearl HW 55 & $30-60$ & $1000-200,000$ & 0.06 \\
Toyopearl HW 65 & $30-60$ & $10,000-1,000-000$ & 0.07 \\
Toyopearl HW 75 & $30-60$ & $100,000-10,000,000$ & 0.06 \\
\hline
\end{tabular}

${ }^{\mathrm{a}}$ Reported as hydrated bead diameter with the exception of the Toyopearl resins which are dry bead diameter.

${ }^{\mathrm{b}}$ Rate high salt TE buffer eluted from a 2-ml packed-volume Poly-Prep column initially loaded with $1 \mathrm{ml}$ of buffer. 
was packed into Disposaflex polypropylene columns (Kimble Glass, Vineland, NJ) to a final volume of $7.5 \mathrm{ml}$. Disposaflex column specifications (I.D. $=8$ $\mathrm{mm}$, length $=200 \mathrm{~mm}$ ) provided for a low cross-sectional area to length ratio compared to the Poly-Prep columns (I.D. $=8 \mathrm{~mm}$, length $=40 \mathrm{~mm}$ ). Two volumes of high salt TE buffer were passed through the columns as a final wash prior to loading sample crude extract. Various volumes of crude DNA extract $(0.25,0.5$ and $1 \mathrm{ml})$ were applied to the columns to determine whether the columns could effectively remove inhibitory substances from larger volumes of crude extract. High salt TE buffer was used to elute the DNA and humic acids from the column in either 0.5 or $1 \mathrm{ml}$ fractions. Fractions were stored at $-20^{\circ} \mathrm{C}$ until analysis. All treatments (Sephadex 2B versus $4 \mathrm{~B}$ and variable crude extract volumes) and the three crude extracts (cattle feedlot-gentle chemical lysis, cattle feedlot-bead mill homogenization, and aquifer sediment-gentle chemical lysis) were run in duplicate.

\subsection{Analytical techniques}

DNA content in each column fraction was determined by comparison to the unpurified crude extract using agarose gel electrophoresis and image analysis. Briefly, equivalent amounts of crude extract and purified column fraction were loaded onto a $1 \%$ agarose gel and run for $25 \mathrm{~min}$ at $5 \mathrm{v} / \mathrm{cm}$. After staining with ethidium bromide (Sambrook et al.,
1989), an image of the gel was taken using a UVP imaging system (UVP Laboratory Products, Upland, CA) under UV illumination. NIH Image analysis software was then used to quantify the amount of DNA in the crude extract and in each fraction, and the DNA values were standardized to reflect the percentage of DNA in the crude extract recovered in each column fraction.

Humic acid concentration was determined by comparing the absorbance of each fraction to the absorbance of several dilutions of crude extract at $320 \mathrm{~nm}$ using Beckman DU 640 spectrophotometer (Beckman Coulter, Fullerton, CA). Humic acids have very similar spectral properties to nucleic acids with peak absorbance in the UV range. By examining higher wavelengths, we found that absorbance at 320 $\mathrm{nm}$ was independent of DNA content and served as a good proxy for the degree of humic acid contamination. Similarly, $A_{320}$ correlated strongly $\left(R^{2}=0.911\right)$ with the level of PCR contamination, i.e., extracts with higher absorbance required more dilution for successful PCR amplification.

A PCR inhibition assay (Miller et al., 1999) was used to quantify the degree of PCR inhibition (PCR threshold) in pooled DNA fractions (see Table 4) from each of the resins tested. From two to five of the fractions containing DNA were pooled from both duplicate Poly-Prep columns to yield a sample containing $90 \%$ of the DNA in the crude extract. DNA and humic acid concentrations in the pools were then determined as described above. Varying amounts of

Table 4

Humic acid content and PCR inhibition threshold in the pooled Poly-Prep column fractions

\begin{tabular}{|c|c|c|c|c|}
\hline Resin & $\begin{array}{l}\text { Fractions } \\
\text { pooled }^{\text {a }}\end{array}$ & $\begin{array}{l}\text { DNA } \\
\text { (\% of crude extract) }\end{array}$ & $\begin{array}{l}\text { Humic acids } \\
\text { (\% of crude extract) }\end{array}$ & $\begin{array}{l}\text { PCR inhibition threshold } \\
\text { (\% of reaction volume) }\end{array}$ \\
\hline Crude extract & NA & 100 & 100.00 & 0.016 \\
\hline Sephadex G150 & $3,4,5$ & 93.0 & 3.00 & 0.250 \\
\hline Sephadex G200 & $2,3,4$ & 99.8 & 2.35 & 0.500 \\
\hline Sepharose 2B & $3,4,5$ & 90.5 & 0.30 & 16.000 \\
\hline Sepharose 4B & 4,5 & 89.1 & 0.31 & 8.000 \\
\hline Sepharose 6B & 4,5 & 99.0 & 0.38 & 4.000 \\
\hline Bio-Gel P100 & $2,3,4$ & 96.2 & 2.06 & 0.500 \\
\hline Bio-Gel P200 & $2,3,4$ & 100.3 & 3.10 & 0.250 \\
\hline Toyopearl HW 55 & $4,5,6$ & 102.4 & 3.91 & 0.250 \\
\hline Toyopearl HW 65 & $4,5,6$ & 96.6 & 0.66 & 8.000 \\
\hline Toyopearl HW 75 & $3,4,5,6,7$ & 78.8 & 1.93 & 1.000 \\
\hline
\end{tabular}

${ }^{\mathrm{a}}$ Fractions selected for recovery of $90 \%$ of crude extract DNA.

${ }^{\mathrm{b}}$ Highest percentage of contribution of purified DNA extract in the PCR reaction that results in a PCR product of the expected size. 
the pooled extract were then added to a $25 \mu$ l (final volume) PCR reaction spiked with $0.5 \mathrm{ng}$ of Nitrosomonas eutropha DNA. Although conditions in the soil samples were appropriate for nitrifying bacteria, we spiked the reactions with template to ensure that a negative PCR reaction was attributable only to the presence of inhibitory substances and not the lack or quality of template DNA. Each PCR reaction con-

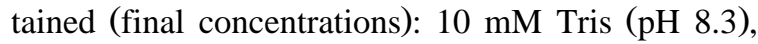
$50 \mathrm{mM} \mathrm{KCl}, 1.5 \mathrm{mM} \mathrm{MgCl}_{2}, 0.5 \mu \mathrm{M}$ of each nitrifier-specific oligonucleotide PCR primer, NITB (5'-ACCCATCCCGAAGTGTGCATT) (Voyteck and Ward, 1995) and Nso190R (5'-GGAGAAAAGCAGGGGATCG) (Mobarry et al., 1996), $50 \mu \mathrm{M}$ dNTP, and 1 unit Taq polymerase (Fisher Scientific, Pittsburg, PA). The following PCR temperature cycle was used to amplify nitrifying 16s rRNA genes: $80^{\circ} \mathrm{C}$ hot start followed by 35 cycles of $95^{\circ} \mathrm{C}(1$ $\mathrm{min}), 55^{\circ} \mathrm{C}(1 \mathrm{~min})$, and $72^{\circ} \mathrm{C}(1.5 \mathrm{~min})$. After cycling, the reactions were subjected to a final $5 \mathrm{~min}$ extension at $72^{\circ} \mathrm{C}$. The presence of a PCR product in the various dilutions was determined by agarose gel electrophoresis. The lowest dilution of a pooled sample that produced a PCR product of the expected size corresponded to the PCR inhibition threshold. For instance, successful PCR from the crude extract occurred when the crude extract made up $0.016 \%$ or less of the PCR reaction volume, while extract purified by Sephadex G150 produced the expected PCR product at volumes up to $0.25 \%$ of the PCR reaction volume. Highly contaminated extracts required considerable dilution for successful PCR and had low inhibition thresholds.

\section{Results and discussion}

\subsection{Initial screening of gel filtration resins}

DNA and humic acids showed different mobility through the four types of gel filtration resins tested (Fig. 1). For all resins tested in the 2-ml Poly-Prep columns, DNA moved quickly through and usually eluted within the first milliliter of liquid, while the dark brown humic acids were retained in the resins. Sephadex and Bio-Gel $\mathrm{P}$ resins had very similar characteristics with respect to the way humic acids were eluted (Fig. 1A and C). Humic acids eluted during the entire elution, and DNA fractions showed low, but significant humic acid contamination. In contrast, the Sepharose and Toyopearl resins showed much better separation of DNA and humic acids (Fig. 1B and D). All Sepharose resins and Toyopearl HW 65 were able to separate the DNA from humic acids in the sample. The other two Toyopearl resins (HW 55 and HW 75) showed some degree of contamination. The variation between duplicate columns was very low, regardless of resin tested. For instance, the average coefficient of variation for the Sephadex resins (Fig. 1A) was $5.9 \%$ and $7.1 \%$ for DNA and humic acids, respectively.

We conclude that the apparent molecular weight of a small portion $(<4 \%)$ of the humic acids in the cattle feedlot crude extract exceeds 200,000 Daltons (relative to globular proteins), because of the coelution of DNA and humic acids in the Sephadex, Bio-Gel P, and Toyopearl HW 55 resins tested. An upper limit for humic acid apparent molecular weight is less than 1,000,000 Daltons, because the DNA was efficiently separated from humic acids using the Sepharose and Toyopearl HW 65 and 75 resins. The bulk of humic acids, however, had apparent molecular weights below 150,000 Daltons as evidenced by humic acid retention in the Bio-Gel P100 and Sephadex G150 resins. Sepharose and Toyopearl HW 65 and 75 resins were able to efficiently separate DNA from humic acids in the crude extracts, because the apparent molecular weight of DNA in the feedlot DNA extract exceeded 20,000,000 Daltons. In reality, DNA fragments ranged from 3.1 to $40 \mathrm{~kb}$ or $2,000,000$ to $25,000,000$ Daltons. Although the range of DNA sizes falls within the MW fractionation range for many of the resins tested, there was no retention of DNA within the resin matrix. This is likely due to shape of the DNA molecules (long strands) compared to globular proteins (much more spherical). Deviations from a truly spherical shape make particles less likely to enter the resin pores, and they behave as if they have a larger MW. It is likely that humic acids are similar in shape to DNA. Thus, our MW size estimation for humic acids may be considerably lower than the actual size. Regardless of the actual versus apparent molecular weight, it is the difference in the apparent molecular weights that enable the easy separation of DNA from humic acids in gel filtration chromatography. 

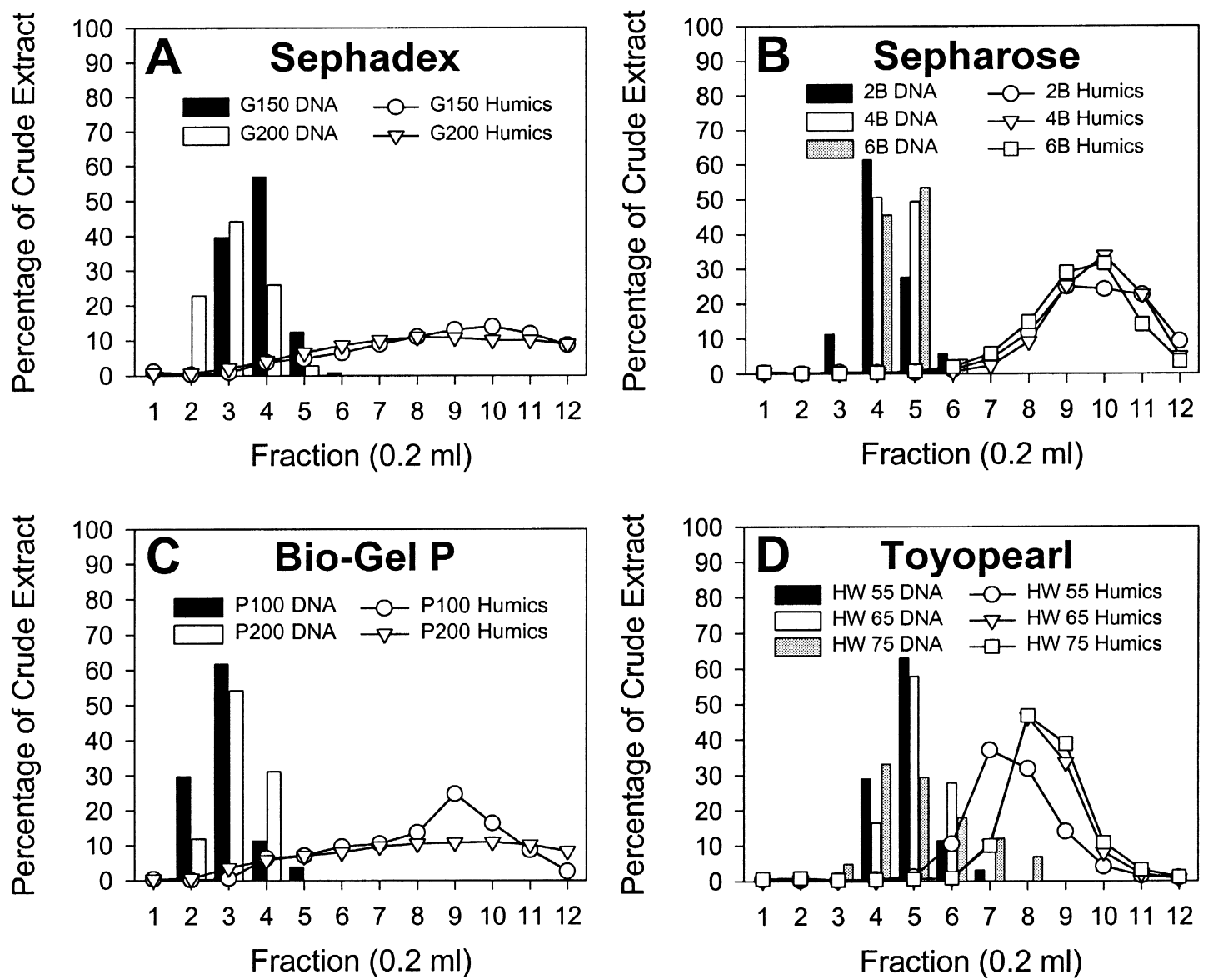

Fig. 1. Comparison of gel filtration resins in Poly-Prep columns for the ability to separate DNA from humic acids in cattle feedlot soil crude extracts. Resin was packed in duplicate columns to a $2-\mathrm{ml}$ volume, and the volume of crude extract applied to each column was $0.2 \mathrm{ml}$. The average DNA and humic acid recoveries for each fraction are expressed as a percentage of DNA or humic acids in the unpurified crude extract.

Pooled column fractions containing roughly $90 \%$ of the DNA in the crude extract showed varying degrees of humic acid contamination (Table 4). Purification efficiency, the percentage of humic acids removed from the pooled fraction, was relatively high, ranging from 96.1 to $99.7 \%$. Small differences in the purification efficiency, however, resulted in large differences in the ability to PCR amplify. For instance, decreasing the humic acid content of a sample 10 -fold (from $3 \%$ to $0.3 \%$ of the crude extract concentration) resulted in a 64-fold increase of the PCR threshold (compare Sephadex G150 to Sepharose 2B). This is particularly important if the target sequence is very rare, and dilution of the purified extract for successful PCR amplification would also dilute the target sequence beyond the limit of detection.

These results from our initial experiments using the Poly-Prep columns are consistent with the results of Jackson et al. (1997). We confirm that Sepharose resins are more efficient than Sephadex resins at purifying humic acids away from DNA in soil and sediment extracts. Furthermore, we find that Sepharose resins are superior to Bio-Gel $\mathrm{P}$ resins based upon separation of humic acids and DNA. We also conclude that Sepharose resins are easier to use 
than the Toyopearl resins because of Sepharose's higher gravity-flow rates.

\subsection{Development and evaluation of large-volume capacity gel filtration columns}

Large crude extract capacity columns were developed and tested using Sepharose resins. Our objectives were to: (i) determine the optimum Sepharose resin for DNA purification; (ii) increase the column capacity to accommodate $1 \mathrm{ml}$ crude extract samples; (iii) minimize column expense/maximize reusability; and (iv) ensure that crude extracts from various sources prepared using different methods could be easily purified. Building upon the work of Jackson et al. (1997), we were interested to see if there were any differences between Sepharose resins (only Sepharose 4B was examined in their study). Based upon our initial experiments with the Poly-Prep columns, we found that humic acids and DNA separated consistently much better using Sepharose 2B and 4B versus Sepharose 6B (Fig. 1B). In a side-byside comparison using Disposaflex columns packed with 7.5-ml of resin, DNA eluted much faster from Sepharose 2B versus Sepharose 4B, while humic acids were identically retained (Fig. 2A). Based upon the assumption that better separation results in lower humic acid contamination in the DNA fractions, we conclude that Sepharose 2B is superior to Sepharose 4B.

Under the conditions employed in this study, maximum extract capacity for the Poly-Prep columns was roughly $1 / 10$ the resin volume $(0.2 \mathrm{ml})$. We also have found the same volume limitations $(<0.5$ $\mathrm{ml}$ depending upon syringe size) with spin columns (Miller et al., 1999). Additionally, we find that spin column preparation was unduly labor intensive, and spin columns often became clogged during centrifugation. In our hands, gravity-flow columns were easier to set up, more reproducible, and could be more easily scaled up to work with dozens of samples. Disposaflex columns also could accommodate samples in excess of $1 / 10$ the resin volume with little effect on DNA purification (Fig. 2B). In addition to their low column capacity, we found that the bed supports in the Poly-Prep columns tended to get dirty. Disposaflex columns could be easily disassembled, cleaned, and autoclaved. Dirty bed supports were easily replaced. Finally, the low cost of the Disposaflex columns ( $<\$ 1$ per column) increased the attractiveness of these columns as an alternative to other available chromatography and spin columns.

A final evaluation of the Sepharose 2B, largevolume capacity method was made using three different crude extracts prepared from two very different samples using the two most common DNA extraction techniques, gentle chemical lysis and bead mill homogenization. Although the crude extracts varied in the DNA quantity, DNA fragment sizes, and humic acid content (Table 2), elution of the DNA and humic fractions were similar (Fig. 2C). Low humic acid recovery from the bead mill homogenization extract of feedlot soil resulted from an initially low concentration of humic acids relative to the gentle chemical lysis extract of feedlot soil. DNA recovery after purification exceeded $90 \%$ for all extracts when compared to the DNA content of the crude extract. Humic acid contamination in the purified samples was $0.013 \%$ for the aquifer extract, $0.011 \%$ for the feedlot ditch sample (gentle lysis), and $0.038 \%$ for the feedlot ditch sample (bead mill homogenization), which was 10 -fold purer than extract purified using the Poly-Prep columns (see Table 4). In tests to determine the PCR inhibition threshold, PCR reactions containing $20 \%$ of the volume of purified DNA extract produced PCR product. This level was equal to the inhibition threshold for high salt TE alone (elution buffer). Thus, PCR-inhibitory compounds present in the crude extracts were completely removed. In additional experiments, we found that bacterial $16 \mathrm{~S}$ rDNA genes could be easily PCRamplified from these samples even when Nitrosomonas eutropha DNA was omitted from the reaction.

In summary, Sepharose 2B possessed the best properties for purifying DNA in sediment crude extracts. Gel filtration resins with size fractionation ranges greater than and lower than the apparent molecular weight of the humic acids and DNA fragments, respectively, in the extract proved most effective. Other gel filtration resins (i.e., Bio-Gel A from Bio-Rad) possessing these characteristics should also work well. In our experiments using Sepharose 2B, we easily recovered greater than $90 \%$ of the DNA from a crude extract while limiting humic acid recovery to less than $0.04 \%$. Furthermore, target se- 

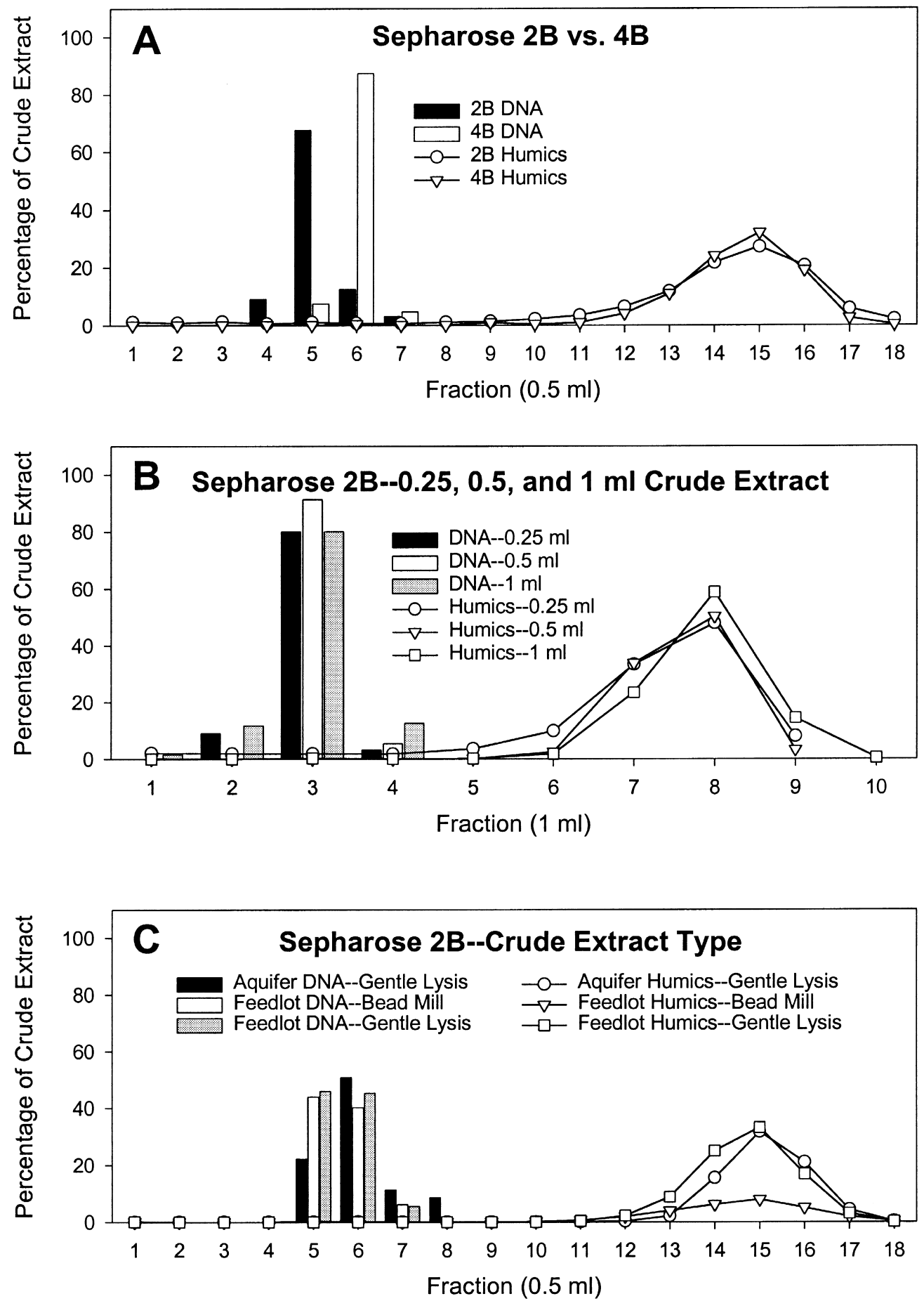

Fig. 2. Evaluation of Sepharose $2 B$ and 4B resins in Disposaflex columns with varying crude extract volumes and crude extract types. Resin was packed in duplicate columns to a $7.5-\mathrm{ml}$ volume, and the volume of crude extract applied to each column was $0.5 \mathrm{ml}$ except where stated to the contrary. 
quences could be PCR-amplified even when purified extract comprised up to $20 \%$ of the reaction volume. Finally, a large-volume capacity, gravity-flow procedure was developed and proved effective at purifying DNA from crude extracts. Scaling-up to even larger volumes is possible with larger columns, but cost becomes an issue.

It is possible that samples from different sources will contain humic acids and DNA with mobility properties that differ from the samples tested in this study. Although our samples where initially selected to represent very different types of samples and confound purification, DNA purification was very similar regardless of sample origin or extraction method employed. However, it may be necessary to vary the resin to optimize the separation of DNA from humic acids from some soil samples. It should also be emphasized that while some gel filtration resins are highly effective at purifying DNA, they are unsuitable for RNA purification, because low molecular weight RNAs co-elute with humic acids. This work should provide a framework for understanding the critical factors to produce highly pure DNA from soil crude extracts.

\section{Acknowledgements}

We would like to thank Kelli Jensen for her expert technical assistance, Jeff Waechter and Jennie Barkhoff for conducting soil analyses, and Sherry Hansen and Jan Watts for help in manuscript preparation. We are also grateful to Dr. Richard L. Smith for the gift of aquifer sediment.

\section{References}

Barber II, L.B., Thurman, E.M., Schroeder, M.P., LeBlanc, D.R., 1988. Long-term fate of organic micropollutants in sewagecontaminated groundwater. Environ. Sci. Technol. 22, $205-$ 211.

Harvey, R.W., Barber II, L.B., 1992. Associations of free-living bacteria and dissolved organic compounds in a plume of contaminated groundwater. J. Contam. Hydrol. 9, 91-103.

Jackson, C.R., Harper, J.P., Willoughby, D., Rosen, E.E., Churchill, P.F., 1997. A simple, efficient method for separa- tion of humic substances and DNA from environmental samples. Appl. Environ. Microbiol. 63, 4993-4995.

LeBlanc, D.R., 1984. Sewage plume in a sand and gravel aquifer, Cape Cod, Massachusetts. US Geological Survey Water Supply Paper 2218. U.S. Geological Survey, Washington, DC.

Leff, L.G., Dana, J.R., McArthur, J.V., Shimkets, L.J., 1995. Comparison of methods of DNA extraction from stream sediments. Appl. Environ. Microbiol. 61, 1141-1143.

Miller, D.N., Bryant, J.E., Madsen, E.L., Ghiorse, W.C., 1999. Evaluation and optimization of DNA extraction and purification procedures for soil and sediment samples. Appl. Environ. Microbiol. 65, 4715-4724.

Mobarry, B.K., Wagner, M., Urbain, V., Rittmann, B.E., Stahl, D.A., 1996. Phylogenetic probes for analyzing abundance and spatial organization of nitrifying bacteria. Appl. Environ. Microbiol. 62, 2156-2162.

Moré, M.I., Herrick, J.B., Silva, M.C., Ghiorse, W.C., Madsen, E.L., 1994. Quantitative cell lysis of indigenous microorganisms and rapid extraction of microbial DNA from sediment. Appl. Environ. Microbiol. 60, 1572-1580.

Sambrook, J., Fritsch, E.F., Maniatis, T., 1989. Molecular Cloning: A Laboratory Manual. 2nd Edition Cold Spring Harbor Laboratory Press, Cold Spring Harbor, NY.

Savoie, J., LeBlanc, D.R., 1998. Water-quality and methods of analysis for samples collected near a plume of sewage-contaminated ground water, Ashumet Valley, Cape Cod, Massachusetts, 1993-1994. US Geological Survey Water-Resources Investigations Report 97-4269. U.S. Geological Survey, Washington, DC.

Smith, R.L., Howes, B.L., Duff, J.H., 1991. Denitrification in nitrate-contaminated groundwater: occurrence in steep vertical geochemical gradients. Geochim. Cosmochim. Acta 55, 18151825.

Steffan, R.J., Goksoyr, J., Bej, A.K., Atlas, R.M., 1988. Recovery of DNA from soils and sediments. Appl. Environ. Microbiol. 54, 2908-2915.

Straub, T.M., Pepper, I.L., Gerba, C.P., 1995. Removal of PCR inhibiting substances in sewage sludge amended soil. Water Sci. Technol. 31, 311-315.

Tsai, Y., Olson, B.H., 1992. Detection of low numbers of bacterial cells in soils and sediments by polymerase chain reaction. Appl. Environ. Microbiol. 58, 754-757.

Voyteck, M.A., Ward, B.B., 1995. Detection of aamonium-oxidizing bacteria of the beta subclass of the class Proteobacteria in aquatic samples with PCR. Appl. Environ. Microbiol. 61, 1444-1450.

Wilson, I.G., 1997. Inhibition and facilitation of nucleic acid amplification. Appl. Environ. Microbiol. 63, 3741-3751.

Zapico, M.M., Vales, S., Cherry, J.A., 1987. A wireline piston core barrel for sampling cohesionless sand and gravel below the water table. Ground Water Monit. Rev. 7, 74-82.

Zhou, J., Bruns, M.A., Tiedje, J.M., 1996. DNA recovery from soils of diverse composition. Appl. Environ. Microbiol. 62, 316-322. 